\title{
NADP-dependent alcohol dehydrogenases in bacteria and yeast: purification and partial characterization of the enzymes from Acinetobacter calcoaceticus and Saccharomyces cerevisiae
}

\author{
Martin R. Wales† and Charles A. Fewson \\ Author for correspondence: Charles A. Fewson. Tel: +44413398855 ext. 5902. Fax: +44 413304620.
}

Department of Biochemistry, University of Glasgow, Glasgow G12 8QQ, UK

\begin{abstract}
An NADP-dependent constitutive alcohol dehydrogenase that can oxidize hexan-1-ol was detected in several Gram-positive and Gram-negative eubacteria and in two yeasts. The enzyme was purified to homogeneity from Acinetobacter calcoaceticus NCIB 8250 and from Saccharomyces cerevisiae D273-10B. The bacterial enzyme appears to be a tetramer of subunit $M_{r} 40300$ and the yeast enzyme appears to be a monomer of subunit $M_{r} 43500$. The $N-$ terminal amino acid sequence of the bacterial enzyme has $34 \%$ identity with part of the sequence of a fermentative alcohol dehydrogenase from Escherichia coli. The pl value of the bacterial enzyme was 5.7 and the pH optimum was 10.2. Both the bacterial and yeast enzymes were shown to transfer the pro-R hydrogen to/from NADP(H). The substrate specificities of the two enzymes were similar to each other, both oxidizing primary alcohols and some diols, but not secondary alcohols. The maximum velocities of both enzymes were with pentan-1-ol as substrate and there was very low activity with ethanol; the maximum specificity constants were found with primary alcohols containing six to eight carbon atoms. Neither enzyme was significantly inhibited by metal-binding agents but some thiol-blocking compounds inhibited them. It appears that these two alcohol dehydrogenases, one prokaryotic and one eukaryotic, are structurally, kinetically and functionally different from members of the major known groups of alcohol dehydrogenases.
\end{abstract}

Keywords: Acinetobacter calcoaceticus, Saccharomyces cerevisiae, alcohol dehydrogenase

\section{INTRODUCTION}

A great many alcohol dehydrogenases have been purified and characterized; the vast majority of the enzymes studied have been from animals - mostly mammals - or from plants and yeasts (Jörnvall et al., 1987). Much of the interest in these enzymes in recent years has revolved around comparisons of their primary structures. On this basis, alcohol dehydrogenases have been divided into three groups. (1) Those with subunit $M_{\mathbf{r}}$ values of around 40000 (Jörnvall et al., 1987). A great many enzymes are known in this group and they have been considered to be zinc-dependent although zinc has been unambiguously

†Present address: Celltech Research, 216 Bath Road, Slough SL1 4EN, UK. identified in comparatively few of them. (2) The nonmetalloenzymes with subunit $M_{\mathrm{r}}$ values of around 28000 (Thatcher \& Sawyer, 1980; Jörnvall et al., 1981; Baker, 1990). (3) A group of enzymes, initially all thought to contain iron, with subunit $M_{\mathrm{r}}$ values of around 40000 . Metal-ion dependency does not appear to be a sufficient predictor of structural homology since different enzymes of group 3 have been identified as containing zinc or iron and in one case zinc and magnesium (Clark, 1992).

Many of these, predominantly eukaryotic, enzymes are induced under anaerobiosis and/or by alcohols (usually ethanol) and most of them are NAD-dependent. The range of alcohol dehydrogenases in prokaryotic organisms appears to be much greater than that in eukaryotes, but few of the prokaryotic enzymes other than a handful 
of methanol and ethanol dehydrogenases have been studied in much detail (MacKintosh \& Fewson, 1987; Wales \& Fewson, 1991). We therefore decided to study a bacterial alcohol dehydrogenase which is apparently constitutive, i.e. produced during growth on non-alcohol carbon sources under aerobic conditions, which uses NADP rather than NAD as cofactor, and which has maximal activity with primary alcohols with chain lengths greater than that of ethanol. A few such enzymes have been previously identified. Apparently constitutive NADP-dependent alcohol dehydrogenase activities with relatively high $K_{\mathrm{m}}$ values for ethanol and lower $K_{\mathrm{m}}$ values for hexan-1-ol have been partially purified from $M y c o-$ bacterium tuberculosis (DeBruyn et al., 1981) and Pseudomonas aeruginosa (Tassin \& Vandecasteele, 1972). Also, such an activity has been identified in a number of different strains of Acinetobacter including $A$. calcoaceticus NCIB 8250, 69V, EB104 and HO1-N (Tauchert et al., 1976; Fixter \& Nagi, 1984; Asperger \& Kleber, 1991; Fox et al., 1992). An enzyme from $A$. calcoaceticus HO1-N was recently partially purified and some characterization achieved (Fox et al., 1992); however, none of these enzymes has been purified to homogeneity or adequately characterized.

The present paper describes the identification of apparently constitutive NADP-dependent hexan-1-ol dehydrogenase activities in a wide variety of eubacteria, and the purification and partial characterization of the enzyme from a strain of $A$. calcoaceticus. During the course of this work it became apparent that a very similar enzyme was present in yeasts, and one of these eukaryotic enzymes, from Saccharomyces cerevisiae, was purified and characterized sufficiently to allow it to be compared with the prokaryotic enzyme. Some of these results have been published in a preliminary form (Wales \& Fewson, 1991).

\section{METHODS}

Materials. All chemicals used were of the best quality available and most of them were obtained from the sources described by Allison et al. (1985) and MacKintosh \& Fewson (1988) except for those listed below.

Acetaldehyde was from Aldrich, allyl alcohol was from Fisons Scientific Equipment, and cis-hex-3-en-1-ol and hex-5-en-1-ol were from Lancaster Synthesis. Matrex Gel Blue A and Red A were from Amicon. Phenyl-Sepharose, a prepacked Superose 6 column and ferritin were from Pharmacia. Pig-heart lactate dehydrogenase, rabbit-muscle pyruvate dehydrogenase, horsespleen ferritin, horse-heart cytochrome $c, \mathrm{NADP}^{+}$(disodium salt) and NADPH (disodium salt) were from Bochringer. Saccharomyces cerevisiae NAD-dependent alcohol dehydrogenase was from $\mathrm{BDH}$. Materials used in the determination of stereospecificity of hydride transfer to/from $\operatorname{NADP}(\mathrm{H})$ were obtained from the sources described by Baker et al. (1992) except dihydrofolate and dihydrofolate reductase, which were from Sigma.

Growth of micro-organisms and preparation of extracts. Stock cultures of Acinetobacter calcoaceticus NCIB 8250 and Escherichia coli ML30 were maintained at $4{ }^{\circ} \mathrm{C}$ in a complex medium as described by Allison et al. (1985). Stock cultures of Rhodotorula graminis KGX 39 (donated by Genex Corporation, Gaithersberg, MD, USA) and Bacillus subtilis NCIMB 3610 were maintained as lyophilized cultures in a filter-sterilized mixture of three parts heat-inactivated horse serum to one part $30 \%(\mathrm{w} / \mathrm{v})$ glucose. Spores of Streptomyces rimosus 4018 (obtained from Miss L. Drynan of this Department) were stored in sterilized distilled water at $-80^{\circ} \mathrm{C}$. Rbodococcus rbodochrous NCIMB 13259 was maintained at $4{ }^{\circ} \mathrm{C}$ on nutrient agar slopes. Pseudomonas putida NCIMB 9494 and $P$. aeruginosa NCIMB 10548 were maintained at $4{ }^{\circ} \mathrm{C}$ on agar slopes containing a defined medium as described by Murray et al. (1972). Sacch. cerevisiae D273-10B (Reid \& Schatz, 1982) was maintained at $4{ }^{\circ} \mathrm{C}$ on peptone/yeast extract/galactose agar slopes.

All micro-organisms were grown into stationary phase before being harvested, washed and then either used immediately or stored at $-20^{\circ} \mathrm{C}$.

For small-scale growth of $A$. calcoaceticus NCIB 8250, an inoculum $(0.1 \mathrm{ml})$ from a stock culture was transferred to $50 \mathrm{ml}$ of complex medium (Allison et al., 1985) in a $250 \mathrm{ml}$ flask and shaken at 200 r.p.m. for $16 \mathrm{~h}$ at $30^{\circ} \mathrm{C}$. Eight millilitres of this culture was then transferred to $400 \mathrm{ml}$ of the same medium in a 2 litre flask and shaken for $16 \mathrm{~h}$ at $30^{\circ} \mathrm{C}$ before harvesting. Large quantities of $A$. calcoaceticus NCIB 8250 were grown in a complex medium in a 10 litre fermenter fitted with a 20 litre reservoir using essentially the method of Allison et al. (1985). The inoculum used was a $400 \mathrm{ml}$ culture prepared as described above. The fermenter (Braun Biostat V; F. T. Scientific Instruments) was operated at $30^{\circ} \mathrm{C}$ with an aeration rate of 4 litres of sterile air $\mathrm{min}^{-1}$ and stirring at setting 2.5 (approx. 250 r.p.m.). After growth for $20 \mathrm{~h}, 9 \cdot 5$ litres culture was removed for harvesting and $9 \cdot 5$ litres fresh medium transferred to the fermenter from the reservoir. After a further $20 \mathrm{~h}$ growth, $9 \cdot 5$ litres culture was removed for harvesting and the remaining medium transferred from the reservoir. The culture was grown for a final $20 \mathrm{~h}$, then all the culture was removed and harvested.

Stock culture $(0.1 \mathrm{ml})$ of E. coli ML30 was transferred to $50 \mathrm{ml}$ glycerol/salts medium (Holms \& Bennett, 1971) and shaken at 200 r.p.m. for $16 \mathrm{~h}$ at $37^{\circ} \mathrm{C}$. One millilitre of this culture was then transferred to $250 \mathrm{ml}$ of the same medium and shaken at 200 r.p.m. for $24 \mathrm{~h}$ at $37^{\circ} \mathrm{C}$. Four millilitres of this culture was then transferred to 1 litre of the same medium and stirred (using a magnetic stirrer) with aeration $\left(500 \mathrm{ml}\right.$ air $\left.\mathrm{min}^{-1}\right)$ for $24 \mathrm{~h}$ at $37^{\circ} \mathrm{C}$.

A loopful of a culture of $P$. putida NCIMB 9494 or $P$. aeruginosa NCIMB 10548 was transferred to $50 \mathrm{ml}$ of complex medium, containing DL-lactate, in a $250 \mathrm{ml}$ flask and shaken at 200 r.p.m. for $16 \mathrm{~h}$ at $30^{\circ} \mathrm{C}$. Eight millilitres of this culture was then transferred to $400 \mathrm{ml}$ of the same medium in a 2 litre flask and shaken for $24 \mathrm{~h}$ at $30^{\circ} \mathrm{C}$ before harvesting.

B. subtilis NCIMB 3610 was plated out on a sterile nutrient agar plate which was then incubated for $24 \mathrm{~h}$ at $30^{\circ} \mathrm{C}$. One colony was used to inoculate $10 \mathrm{ml}$ sterile nutrient broth, which was then incubated for $24 \mathrm{~h}$ at $30^{\circ} \mathrm{C}$. Five millilitres of this culture was transferred to $500 \mathrm{ml}$ sterile nutrient broth (in a 2 litre flask) and shaken for $16 \mathrm{~h}$ at $30^{\circ} \mathrm{C}$.

A loopful of a culture of Rhodococcus rbodochrous was transferred to $500 \mathrm{ml}$ sterile nutrient broth and shaken at 200 r.p.m. for $72 \mathrm{~h}$ at $30^{\circ} \mathrm{C}$.

Spores of Strep. rimosus 4018 suspended in distilled water $(0 \cdot 1 \mathrm{ml})$ were transferred to 1 litre yeast extract/malt extract medium (Hopwood et al., 1985) in a 2 litre flask and shaken at 200 r.p.m. for $72 \mathrm{~h}$ at $30^{\circ} \mathrm{C}$. Cells were harvested and $1 \mathrm{~g}$ of pellet was resuspended in $100 \mathrm{ml}$ modified minimal medium (Hobbs et al., 1989) and shaken at 200 r.p.m. for $24 \mathrm{~h}$ at $30^{\circ} \mathrm{C}$. For small-scale growth of Sacch. cerevisiae D273-10B, a loopful of culture was transferred to $50 \mathrm{ml}$ peptone/yeast extract/ 
galactose medium (Reid \& Schatz, 1982) in a $250 \mathrm{ml}$ flask and shaken at 200 r.p.m. for $20 \mathrm{~h}$ at $30^{\circ} \mathrm{C}$. Four millilitres of this culture was then transferred to $400 \mathrm{ml}$ of the same medium in a 2 litre flask and shaken for $20 \mathrm{~h}$ at $30^{\circ} \mathrm{C}$ before harvesting. Larger amounts of Sacch. cerevisiae D273-10B were obtained by inoculating $80 \mathrm{ml}$ of culture prepared as described above into 4 litre peptone/yeast extract/galactose medium in a 10 litre flask. The culture was grown for $20 \mathrm{~h}$ at $30^{\circ} \mathrm{C}$ with stirring and aeration $\left(500 \mathrm{ml}\right.$ sterile air $\left.\mathrm{min}^{-1}\right)$.

Rhodotorula graminis KGX 39 was inoculated into $50 \mathrm{ml}$ nutrient broth in a $250 \mathrm{ml}$ flask and shaken at 250 r.p.m. for $24 \mathrm{~h}$ at $30^{\circ} \mathrm{C}$. Eight millilitres of this culture was then transferred to $400 \mathrm{ml}$ nutrient broth in a 2 litre flask and shaken for $24 \mathrm{~h}$ at $30{ }^{\circ} \mathrm{C}$ before harvesting.

In all cases the micro-organisms were suspended in $50 \mathrm{mM}$ Tris/ $\mathrm{HCl}$ containing $2 \mathrm{mM}$ DTT, $\mathrm{pH} 8 \cdot 0$, before disruption. Ultrasonic disruption was carried out using a LucasDawes soniprobe. An ice/water slurry was used to cool the soniprobe and the cell suspension. E. coli, P. putida and $P$. aeruginosa were suspended in buffer so that the equivalent $\mathrm{OD}_{500}$ was 50 , and broken by $4 \times 30 \mathrm{~s}$ periods of exposure to $90 \mathrm{~W}$, alternating with $3 \times 30 \mathrm{~s}$ cooling periods. Strep. rimosus $(1 \mathrm{~g}$ wet wt) was suspended in buffer $(6 \mathrm{ml})$ and broken by $10 \times 15 \mathrm{~s}$ exposure to $45 \mathrm{~W}$, alternating with $10 \times 15 \mathrm{~s}$ cooling periods. $B$. subtilis was suspended in buffer so that the equivalent $\mathrm{OD}_{500}$ was 50 , and broken by $5 \times 30 \mathrm{~s}$ periods of exposure to $90 \mathrm{~W}$, alternating with $4 \times 30 \mathrm{~s}$ cooling periods. In all cases the homogenates were centrifuged at top speed in an MSE Microcentaur centrifuge for $10 \mathrm{~min}$ at $4{ }^{\circ} \mathrm{C}$ and the supernatants were used immediately or stored at $-20^{\circ} \mathrm{C}$. For disruption of A. calcoaceticus, Rbodotorula graminis, Rhodococcus rbodocbrous and Sacch. cerevisiae in the French pressure cell, the bacteria and the yeasts were suspended in three vols $50 \mathrm{mM}$ Tris/ $\mathrm{HCl}$ containing $2 \mathrm{mM} \mathrm{DTT}, \mathrm{pH} 8 \cdot 0$, and broken by three passages through a pressure cell (FA-073 or FA-003 models; American Instrument Company), which had been pre-cooled in ice, at a pressure of $98 \mathrm{MPa}$. The homogenates were centrifuged at $100000 \mathrm{~g}$ for $1 \mathrm{~h}$ at $4{ }^{\circ} \mathrm{C}$ and the supernatants used immediately or stored at $-20^{\circ} \mathrm{C}$.

Measurement of enzyme activities. All enzyme assays were done in duplicate at $27^{\circ} \mathrm{C}$. One unit of enzyme activity is defined as $1 \mu \mathrm{mol}$ of substrate converted per min.

(i) NADP-dependent alcohol dehydrogenase of $A$. calcoaceticus. The oxidation of hexan-1-ol was measured in an assay mixture containing: $800 \mu \mathrm{l} 100 \mathrm{mM}$ glycine $/ \mathrm{NaOH}$ buffer, pH $10 \cdot 2$ (assay concentration $80 \mathrm{mM}$ ), containing $25 \mathrm{mM}$ hexan1 -ol (assay concentration $20 \mathrm{mM}$ ); $100 \mu 10 \mathrm{mM} \mathrm{NADP}^{+}$(assay concentration $1 \mathrm{mM}$ ); enzyme; and water to $1 \mathrm{ml}$. The rate of $\mathrm{NADP}^{+}$reduction was measured spectrophotometrically at $340 \mathrm{~nm}$.

Alcohols with $>10$ carbons were 'solubilized' in buffer using a method adapted from Tassin \& Vandecasteele (1971). Alcohols were added to $0 \cdot 111 \mathrm{M}$ glycine/ $\mathrm{HCl}$ buffer containing $0.7 \mathrm{mg} \mathrm{BSA} \mathrm{ml}^{-1}$ to give a final concentration $10 / 9$ times that desired in the buffer when made up to volume (i.e. $0.625 \mathrm{mM}$ or less). The glycine/alcohol solution was sonicated between five and ten times at $120 \mathrm{~W}$, the $\mathrm{pH}$ adjusted to $10 \cdot 2$ with $\mathrm{NaOH}$, and the buffer made up to volume with a solution of $0.7 \mathrm{mg} \mathrm{BSA} \mathrm{ml} \mathrm{m}^{-1}$. The enzyme was then assayed as described above except that the sonicated buffer/alcohol solution was used in the reaction mixture. In all cases, the final concentration of alcohol in the buffer was $0.5 \mathrm{mM}$ or less.

The reduction of butanal was measured in an assay mixture containing: $2.4 \mathrm{ml} 100 \mathrm{mM}$ bisTris/ $\mathrm{HCl}$ buffer, $\mathrm{pH} 6.8$ (assay concentration $80 \mathrm{mM}$ ); $0.3 \mathrm{ml} 300 \mathrm{mM}$ butanal (assay con- centration $30 \mathrm{mM}$ ); $0.2 \mathrm{ml} 300 \mu \mathrm{M}$ NADPH (assay concentration $20 \mu \mathrm{M}$ ) ; enzyme; and water to $3 \mathrm{ml}$. The rate of oxidation of NADPH was monitored at $340 \mathrm{~nm}$ (excitation) $/ 460 \mathrm{~nm}$ (emission) in a Perkin-Elmer LS-5 luminescence spectrophotometer with an RA $100 \mathrm{~A}$ recorder using a $3 \mathrm{ml}$ fluorimetric cuvette (Hughes and Hughes) with a $1 \mathrm{~cm}$ light path. Reaction velocities were calculated initially in arbitrary fluorescence units $\min ^{-1}$ (mg protein) $)^{-1}$, and converted into enzyme units (mg protein $)^{-1}$ using a calibration curve of NADPH against arbitrary fluorescence units prepared each time the fluorimeter was used.

(ii) NADP-dependent alcohol dehydrogenase of Sacch. cerevisiae D273-10B. The enzyme was assayed in terms of alcohol oxidation in the same way as described above except that the $\mathrm{pH}$ value of the buffer was $10 \cdot 7$. Aldehyde reduction was assayed as described above.

(iii) NAD-dependent alcohol dehydrogenase from Sacch. cerevisiae. This enzyme was assayed as described for NADP. dependent alcohol dehydrogenase of $A$. calcoaceticus NCIB 8250 except that $1 \mathrm{mM} \mathrm{NAD}{ }^{+}$and $250 \mathrm{mM}$ ethanol were used instead of $1 \mathrm{mM} \mathrm{NADP}{ }^{+}$and $25 \mathrm{mM}$ hexan-1-ol, respectively.

Determination of kinetic constants. Steady-state kinetic data were analysed by the Direct-Linear method (Eisenthal \& Cornish-Bowden, 1974) using the Enzpack computer program (Williams, 1985). Apparent equilibrium constants were determined essentially as described by Baker \& Fewson (1989). Results are given as the mean values \pm standard deviations, with the number of experiments used to obtain these values shown in parentheses.

Purification of NADP-dependent alcohol dehydrogenase from A. calcoaceticus NCIB 8250. All steps were carried out at $4{ }^{\circ} \mathrm{C}$. The extract was prepared with the French pressure cell as described above and dialysed against $50 \mathrm{mM}$ Tris $/ \mathrm{HCl} /$ 2 mM DT'T, pH 8.0.

Step 1: ion-exchange chromatography on DEAE-Sephacel. Dialysed extract (approx. $35 \mathrm{ml}$ ) was applied at $35 \mathrm{ml} \mathrm{h}^{-1}$ to a column of DEAE-Sephacel $(2 \cdot 6 \times 14 \mathrm{~cm})$ pre-equilibrated with $50 \mathrm{mM}$ Tris $/ \mathrm{HCl} / 2 \mathrm{mM}$ DTT, $\mathrm{pH} 8 \cdot 0$. Once loaded, and after allowing $15 \mathrm{~min}$ for protein binding, the column was washed with at least five column volumes of the same buffer at $35 \mathrm{ml} \mathrm{h}^{-1}$ until the $A_{280}$ of the effluent was $<0.05$. Then, elution was carried out with a linear $0-0.3 \mathrm{M} \mathrm{KCl}$ gradient in $50 \mathrm{mM}$ Tris/ $\mathrm{HCl} / 2 \mathrm{mM}$ DTT, pH $8.0(500 \mathrm{ml})$, at a flow rate of $35 \mathrm{ml} \mathrm{h}^{-1}$. Fractions of $5.83 \mathrm{ml}$ were collected and those with peak activity were pooled and concentrated to $<15 \mathrm{ml}$ in dialysis tubing using $\mathrm{CM}$-cellulose. The dialysis tubing was cleaned of CM-cellulose every hour.

Step 2: gel-filtration chromatography through Sephacryl S300HR. The concentrated DEAE-Sephacel pool was applied at $25 \mathrm{ml} \mathrm{h}^{-1}$ to a column of Sephacryl S300HR $(2 \mathrm{~cm} \times 84 \mathrm{~cm})$ and then the enzyme was eluted with $50 \mathrm{mM}$ Tris $/ \mathrm{HCl}$ $2 \mathrm{mM}$ DTT, pH 8.0 at $25 \mathrm{ml} \mathrm{h}^{-1}$. Fractions of $6.25 \mathrm{ml}$ were collected and those with peak activity were pooled.

Step 3 : hydrophobic-interaction chromatography on phenylSepharose CL-4B. $\left(\mathrm{NH}_{4}\right)_{2} \mathrm{SO}_{4}$ was added to the Sephacryl S300HR pool to a final concentration of $5 \%(\mathrm{w} / \mathrm{v})$, then it was applied at $27 \mathrm{ml} \mathrm{h}^{-1}$ to a column of phenyl-Sepharose $(2.6 \mathrm{~cm} \times 10 \mathrm{~cm})$. After allowing $15 \mathrm{~min}$ for the protein to bind, the column was washed at $27 \mathrm{ml} \mathrm{h}^{-1}$ with at least five column volumes of $50 \mathrm{mM}$ Tris $/ \mathrm{HCl} / 2 \mathrm{mM} \mathrm{DTT} / 5 \%(\mathrm{w} / \mathrm{v}$ ) $\left(\mathrm{NH}_{4}\right)_{2} \mathrm{SO}_{4}, \mathrm{pH} 8.0$, until the $A_{280}$ of the effluent was $<0.05$. The enzyme was eluted with $40 \%(\mathrm{v} / \mathrm{v})$ ethanediol in $50 \mathrm{mM}$ Tris $/ \mathrm{HCl} / 2 \mathrm{mM}$ DTT, $\mathrm{pH} 8.0$. Fractions of $6.75 \mathrm{ml}$ were collected and those with peak activity were pooled. 
Step 4: dye-affinity chromatography through Matrex Gel Blue A. The phenyl-Sepharose pool was applied at $25 \mathrm{ml} \mathrm{h}^{-1}$ to a column of Matrex Gel Blue A $(2.6 \mathrm{~cm} \times 6 \mathrm{~cm})$. After allowing $15 \mathrm{~min}$ for the protein to bind, the column was washed at $25 \mathrm{ml} \mathrm{h}^{-1}$ with at least five column volumes of $50 \mathrm{mM}$ Tris $/ \mathrm{HCl} / 2 \mathrm{mM}$ DTT, pH $8 \cdot 5$, until the $A_{280}$ of the effluent was $<0.02$. The enzyme was eluted with $50 \mathrm{mM}$ Tris $/ \mathrm{HCl} / 2 \mathrm{mM}$ DTT $/ 1 \mathrm{mM} \mathrm{NADP}+/ 5 \mathrm{mM}$ hexan-1ol, $\mathrm{pH} 8.5$ and collected over ice in a reservoir.

Step 5: concentration of Matrex Gel Blue A eluate by ionexchange on DEAE-Sephacel. As the eluate from the Matrex Gel Blue A column was collected in the reservoir, it was immediately loaded onto a column of DEAE-Sephacel $(1 \mathrm{~cm} \times 4 \mathrm{~cm})$ at $10 \mathrm{ml} \mathrm{h}^{-1}$. Once loaded, the column was washed with at least two column volumes of $50 \mathrm{mM}$ Tris $/ \mathrm{HCl} / 2 \mathrm{mM}$ DTT, $\mathrm{pH} 8.0$, before elution with $50 \mathrm{mM}$ Tris $/ \mathrm{HCl} / 2 \mathrm{mM}$ DTT $/ 0 \cdot 3 \mathrm{M} \mathrm{KCl}, \mathrm{pH} 8 \cdot 0$. Fractions of $1 \mathrm{ml}$ were collected and those with peak activity were pooled.

The concentrated pool of pure enzyme was exhaustively dialysed against $50 \mathrm{mM}$ Tris $/ \mathrm{HCl} / 2 \mathrm{mM}$ DTT, $\mathrm{pH} 8.0$, before being stored frozen at $-20^{\circ} \mathrm{C}$.

Purification of NADP-dependent alcohol dehydrogenase from Sacch. cerevisiae D273-10. The enzyme was purified as described for the enzyme from $A$. calcoaceticus NCIB 8250 except that: (i) The preparation of extract, initial dialysis, first ion-exchange, gel filtration and hydrophobic-interaction chromatographic steps were carried out in buffers containing $1 \mathrm{mM}$ benzamidine and $1 \mathrm{mM}$ EDTA. (ii) Elution from the ionexchange column was carried out with a linear $0-1.0 \mathrm{M} \mathrm{KCl}$ gradient. (iii) Pooled active fractions from the ion-exchange column were concentrated by precipitation with $\left(\mathrm{NH}_{4}\right)_{2} \mathrm{SO}_{4}$ to a final saturation of $75 \%$. (iv) The column of Sephacryl S300HR was $94 \mathrm{~cm}$ long. (v) Sample was applied to the phenyl-Sepharose column in $50 \mathrm{mM}$ Tris $/ \mathrm{HCl} / 2 \mathrm{mM}$ DTT only [i.e. in the absence of $\left.\left(\mathrm{NH}_{4}\right)_{2} \mathrm{SO}_{4}\right]$. (vi) The dye-affinity chromatography step was carried out on Matrex Gel Red A (not Blue A) as follows. $\mathrm{MgCl}_{2}(100 \mathrm{mM})$ was added to the phenyl-Sepharose pool to give a final concentration of $5 \mathrm{mM}$. The pool was applied at $20 \mathrm{ml} \mathrm{h}^{-1}$ to a column of Matrex Gel Red A $(2.6 \times 7.5 \mathrm{~cm})$ and the column was washed with at least four column volumes of $50 \mathrm{mM}$ Tris $/ \mathrm{HCl} / 2 \mathrm{mM}$ DTT $/ 50 \mathrm{mM}$ $\mathrm{MgCl}_{2}, \mathrm{pH} 8 \cdot 5$. Enzyme was eluted with $50 \mathrm{mM}$ Tris $/ \mathrm{HCl} /$ $2 \mathrm{mM} \mathrm{DTT}^{\prime} / 5 \mathrm{mM} \mathrm{MgCl}_{2} / 0.2 \mathrm{mM} \mathrm{NADP}{ }^{+}, \mathrm{pH} 8.5$. Fractions of $5 \mathrm{ml}$ were collected and those with peak activity were pooled. No further concentration step was necessary. Pure enzyme was dialysed and stored as described for the enzyme from $A$. calcoaceticus.

Electrophoresis. SDS-PAGE was carried out according to the method of Laemmli (1970) using 2-100 $\mu \mathrm{g}$ protein per track. Slab gels $(19.0 \mathrm{~cm} \times 9.5 \mathrm{~cm} \times 0.15 \mathrm{~cm})$ were stained after electrophoresis using Coomassie Brilliant Blue G250 as described by MacKintosh \& Fewson (1988). Dye-stained gels were scanned using an LKB 2202 Ultroscan laser densitometer.

Determination of $M_{\mathrm{r}}, \mathrm{pl}$ and $\boldsymbol{K}_{\mathrm{eq}}$ values, protein concentrations and conductivities. These were determined essentially as described by Baker \& Fewson (1989).

Protein sequencing. The N-terminus of the NADP-dependent alcohol dehydrogenase of $A$. calcoaceticus NCIB 8250 was sequenced by Dr J. N. Keen at the SERC Protein Sequencing Unit, Department of Biochemistry and Molecular Biology, University of Leeds, UK, on two separate occasions. Run 1 was carried out using an Applied Biosystems 477-A liquid-phase sequencer equipped with on-line phenylthiohydantoin ( $\left.\mathrm{P}^{\prime} \mathrm{TH}\right)$ analysis. Run 2 was carried out by solid-phase sequencing as described by Findlay et al. (1989). This involves automated solid-phase Edman degradation with $\mathrm{PTH}$-amino acids being identified off-line by reverse-phase (C18) microbore HPLC.

Stereospecificity of hydride transfer. The method for the synthesis of tritiated $(4 S)-\left[4-{ }^{3} \mathrm{H}\right] \mathrm{NADPH}$ is based on the fact that glucose-6-phosphate dehydrogenase of Leuconostoc mesenteroides specifically transfers a hydride ion $\left(\mathrm{H}^{-}\right.$, or ${ }^{3} \mathrm{H}^{-}$in the case of tritium) from glucose 6-phosphate to the $s i$-face of the dihydronicotinamide ring of $\mathrm{NAD}^{+}$or $\mathrm{NADP}^{+}$(Arnold et al., 1976). $\left[{ }^{3} \mathrm{H}\right]$ Glucose 6-phosphate was produced by phosphorylation of $\left[1{ }^{3} \mathrm{H}\right]$ glucose by ATP using Sacch. cerevisiae hexokinase. The linked assay was carried out in a mixture $(500 \mu \mathrm{l})$ containing $5 \mathrm{mM}$ potassium phosphate buffer, $60.5 \mu \mathrm{M}\left[1-{ }^{3} \mathrm{H}\right]$ glucose (specific activity $6 \mathrm{Ci} \mathrm{mmol}^{-1} ; 222 \mathrm{GBq} \mathrm{mmol}^{-1}$ ), $500 \mu \mathrm{M} \mathrm{ATP}$, $7 \cdot 4$ units hexokinase, $60.5 \mu \mathrm{M} \mathrm{NADP}^{+}$and 53.3 units of glucose-6-phosphate dehydrogenase. The rate of $\mathrm{NADP}^{+}$reduction was followed at $340 \mathrm{~nm}$ and the reaction was assumed to be at equilibrium when there was no further change in $A_{340}$. Protein was then removed from the mixture by ultrafiltration using a Centricon-10 microconcentrator. The (4S)-[4$\left.{ }^{3} \mathrm{H}\right]$ NADPH was used immediately.

The method for the synthesis of tritiated (4R)-[4- $\left.{ }^{3} \mathrm{H}\right] \mathrm{NADPH}$ is based on the fact that dihydrofolate reductase specifically removes the pro-R-hydrogen from NADPH (Blakely et al., 1963). The filtered reaction mixture containing (4S)-[4${ }^{3} \mathrm{H}$ ]NADPH was incubated with $90 \mathrm{mM}$ dihydrofolate and 0.03 units dihydrofolate reductase. The rate of NADPH oxidation was followed by measuring the change in $A_{\mathbf{3 4 0}}$ and the protein removed. Then the tritiated $\mathrm{NADP}^{+}$was purified by HPLC using a Machery \& Nagel Nucleoseal 7-C18 reversephase column $(25 \mathrm{~cm} \times 4.6 \mathrm{~mm})$ with pre-column $(4 \mathrm{~cm} \times 4.6 \mathrm{~mm})$ run isocratically with $2 \%(\mathrm{v} / \mathrm{v})$ methanol $/ 0.1 \%$ (v/v) trifluoroacetic acid to elute $\mathrm{NADP}^{+}$. Fractions containing $\mathrm{NADP}^{+}$were collected and lyophilized.

Tritiated (4R)- $\left[4-{ }^{3} \mathrm{H}\right] \mathrm{NADPH}$ was produced in a mixture $(500 \mu \mathrm{l})$ containing $10 \mathrm{mM}$ potassium phosphate, $\mathrm{pH} 8.0$, $8.8 \mu \mathrm{M}\left[{ }^{3} \mathrm{H}\right] \mathrm{NADP}^{+}, 50 \mu \mathrm{M}$ glucose 6-phosphate and 27 units glucose-6-phosphate dehydrogenase. The reaction was followed at $340 \mathrm{~nm}$ and the protein removed. The resulting (4R)-[4$\left.{ }^{3} \mathrm{H}\right] \mathrm{NADPH}$ was used immediately.

The incubation of tritiated NADPH with NADP-dependent alcohol dehydrogenase was carried out in the same way on NADP-dependent alcohol dehydrogenases from both $A$. calcoaceticus NCIB 8250 and Sacch. cerevisiae D273-10B. To a reaction mixture $(1 \mathrm{ml})$ containing $10 \mathrm{mM}$ potassium phosphate buffer, $\mathrm{pH} 7 \cdot 0,25 \mathrm{mM}$ butan-1-ol and NADPH (assay concentration $20 \mu \mathrm{M}$ ) was added either $(4 R)-\left[4{ }^{3} \mathrm{H}\right] \mathrm{NADPH}$ (assay concentration $0.7 \mu \mathrm{M}$ ) or $(4 S)-\left[4^{3} \mathrm{H}\right] \mathrm{NADPH}$ (assay concentration $0.5 \mu \mathrm{M})$. The reaction was initiated by addition of NADP-dependent alcohol dehydrogenase $(3 \mu \mathrm{g})$ and followed by measuring the change in $A_{340}$. When the reaction had reached equilibrium, protein was removed. $\mathrm{NADP}^{+}$and butan1 -ol were separated by HPLC. Samples $(<500 \mu \mathrm{l})$ were injected onto a Macherey \& Nagel Nucleoseal 7-C18 reverse-phase HPLC column $(25 \mathrm{~cm} \times 4.6 \mathrm{~mm})$ with pre-column $(4 \mathrm{~cm} \times 4.6 \mathrm{~mm})$ pre-equilibrated with $0.1 \%(\mathrm{v} / \mathrm{v})$ trifluoroacetic acid. NADP ${ }^{+}$was eluted isocratically in $2 \%(\mathrm{v} / \mathrm{v})$ methanol $/ 0.1 \%(\mathrm{v} / \mathrm{v})$ trifluoroacetic acid over $15 \mathrm{~min}$, then butan-1-ol was eluted in $100 \%(\mathrm{v} / \mathrm{v})$ methanol in $0.1 \%(\mathrm{v} / \mathrm{v})$ trifluoroacetic acid over $20 \mathrm{~min}$; in both cases solutions were pumped through the column at $1 \mathrm{ml} \mathrm{min}^{-1}$ and fractions were collected at $1 \mathrm{~min}$ intervals and counted for incorporation of ${ }^{3} \mathrm{H}$. The effluent was monitored between $190 \mathrm{~nm}$ and $370 \mathrm{~nm}$, $\mathrm{NADP}^{+}$being identified by its distinctive absorbance pattern. Butan-1-ol was identified by its co-elution with unlabelled butan-1-ol on a Perkin-Elmer 8700 series gas chromatograph 
Table 1. NADP-dependent hexan-1-ol dehydrogenase activities identified in microorganisms

The results were obtained in the present work and by Tassin \& Vandecasteele (1972) [1], DeBruyn et al. (1981) [2] and Fox et al. (1992) [3]. ND, Not determined.

\begin{tabular}{|c|c|c|}
\hline Organism & $\begin{array}{l}\text { Specific activity } \\
{\left[\text { nmol } \text { min }^{-1}\right.} \\
\left.(\mathrm{mg} \text { protein })^{-1}\right]\end{array}$ & $\begin{array}{c}K_{\mathrm{m}(\mathrm{app})} \\
\text { (hexan-1-ol) } \\
(\mathrm{mM})\end{array}$ \\
\hline Acinetobacter calcoaceticus NCIB 8250 & 104 & $1 \cdot 16$ \\
\hline Acinetobacter calcoaceticus HO1-N [3] & 290 & $0 \cdot 29$ \\
\hline Escherichia coli ML30 & $11 \cdot 0$ & $0 \cdot 88$ \\
\hline Pseudomonas putida NCIMB 9494 & $5 \cdot 4$ & $0 \cdot 46$ \\
\hline Pseudomonas aeruginosa NCIMB 10548 & $7 \cdot 7$ & $1 \cdot 11$ \\
\hline \multirow{2}{*}{ Pseudomonas aeruginosa 196A [1] } & $57 \cdot 8(\mathrm{ADH} 1)$ & 0.79 \\
\hline & $10 \cdot 2(\mathrm{ADH} 2)$ & $1 \cdot 20$ \\
\hline Bacillus subtilis NCIMB 3610 & $2 \cdot 8$ & $7 \cdot 50$ \\
\hline Rbodococcus rbodocbrous NCIMB 13259 & 6.6 & $2 \cdot 86$ \\
\hline Streptomyces rimosus 4018 & $3 \cdot 6$ & $12 \cdot 1$ \\
\hline Mycobacterium tuberculosis var. bovis [2] & $43 \cdot 0$ & ND \\
\hline Saccharomyces cerevisiae D273-10B & $12 \cdot 7$ & 3.35 \\
\hline Rbodotorula graminis KGX 39 & $74 \cdot 0$ & $2 \cdot 16$ \\
\hline
\end{tabular}

with a Chromosorb (Perkin-Elmer) 104 column at $175^{\circ} \mathrm{C}$. Radioactivity $\left({ }^{3} \mathrm{H}\right)$ was measured using an LKB model 1209 Rackbeta liquid-scintillation counter. Samples of up to $500 \mu \mathrm{l}$ were added to $5 \mathrm{ml}$ of Ecoscint A (National Diagnostics) and mixed thoroughly.

\section{RESULTS}

\section{Occurrence of NADP-dependent hexan-1-ol dehydrogenase activities in micro-organisms}

In an attempt to identify any non-fermentative constitutive NADP-dependent alcohol dehydrogenases, various micro-organisms were grown aerobically in batch culture to stationary phase on growth media with non-alcohol carbon sources. Organisms grown in this way were assayed for soluble NADP-dependent hexan-1-ol dehydrogenase activity using the method described for the prokaryotic enzyme in Methods, and the approximate $K_{\mathrm{m} \text { (app) }}$ value of any such activity found was determined (Table 1). Such an activity was found in all of the Gramnegative eubacteria, Gram-positive eubacteria and yeasts tested. In all cases, NADP-dependent ethanol dehydrogenase activity, assayed as described for the $A$. calcoaceticus enzyme except that $0.5 \mathrm{M}$ ethanol was included in the reaction mixture instead of hexan-1-ol, was less than $20 \%$ of the NADP-dependent hexan-1-ol dehydrogenase activity. No such activity was identified in the halophilic archaeobacterium, Haloferax mediterranei.

\section{Purification of the NADP-dependent alcohol dehydrogenases from $A$. calcoaceticus and Sacch. cerevisiae}

Typical purifications of NADP-dependent alcohol dehydrogenases from $A$. calcoaceticus NCIB 8250 and $S$. cerevisiae D273-10B are shown in Table 2. Dialysis of crude extract prior to ion-exchange chromatography was necessary in both purifications in order to ensure consistent binding of the enzyme to the first column. Both enzymes eluted at similar salt concentrations from the ionexchange columns: the prokaryotic enzyme at $100 \mathrm{mM} \mathrm{KCl}$ and the eukaryotic enzyme at $60 \mathrm{mM} \mathrm{KCl}$. Not surprisingly, in view of their different quaternary structures (see below), the enzymes behaved very differently on gel filtration. Both enzymes seem quite hydrophobic, binding to phenyl-Sepharose in the presence of little or no $\left(\mathrm{NH}_{4}\right)_{2} \mathrm{SO}_{4}$ and eluting rapidly in the presence of buffer containing $40 \%(\mathrm{v} / \mathrm{v})$ ethanediol. Different dyeaffinity columns were used to purify the different enzymes to homogeneity although both enzymes bound to each of the dyes under similar conditions. However, the enzymes showed different elution patterns from the respective dyes. The bacterial enzyme eluted in a large volume, necessitating an immediate concentration step, whereas the yeast enzyme eluted in a much smaller volume.

The enzymes were purified to homogeneity as determined by SDS-PAGE and scanning of the resulting gels. Both purifications were reproducible. The purification of the prokaryotic enzyme resulted in $100-400 \mu \mathrm{g}$ of enzyme with a specific activity of $58 \pm 5$ units $(\mathrm{mg} \text { protein })^{-1}$ among ten independent preparations. The eukaryotic enzyme purification resulted in $300-340 \mu \mathrm{g}$ of enzyme with specific activities of 34.0 and 30.8 enzyme units $(\mathrm{mg} \text { protein })^{-1}$ in two independent preparations. Both purifications gave $10-25 \%$ recovery and took about a week to complete.

\section{Relative molecular mass}

The native $M_{\mathrm{r}}$ of the prokaryotic enzyme, estimated by gel-filtration chromatography through a calibrated FPLC Superose 6 column, was $158500(151500,165500)$ 
Table 2. Purification of NADP-dependent alcohol dehydrogenases

Full details of the purification are given in Methods.

\begin{tabular}{|c|c|c|c|c|c|c|}
\hline & $\begin{array}{l}\text { Volume } \\
\text { (ml) }\end{array}$ & $\begin{array}{c}\text { Total } \\
\text { activity } \\
\text { (units) }\end{array}$ & $\begin{array}{c}\text { Total } \\
\text { protein } \\
\text { (mg) }\end{array}$ & $\begin{array}{c}\text { Specific } \\
\text { activity } \\
\text { [units (mg } \\
\text { protein) }{ }^{-1} \text { ] }\end{array}$ & $\begin{array}{c}\text { Yield } \\
(\%)\end{array}$ & $\begin{array}{c}\text { Purification } \\
\text { (-fold) }\end{array}$ \\
\hline \multicolumn{7}{|c|}{ (a) From A. calcoaceticus NCIB 8250} \\
\hline Dialysed extract & $45 \cdot 5$ & 141 & 1442 & $0 \cdot 10$ & 100 & 1 \\
\hline DEAE-Sephacel & $56 \cdot 0$ & 139 & $86 \cdot 8$ & 1.61 & 99 & 16 \\
\hline CM-Cellulose & $11 \cdot 8$ & 129 & $90 \cdot 7$ & $1 \cdot 42$ & 92 & 14 \\
\hline Sephacryl S300HR & $63 \cdot 0$ & 70 & $19 \cdot 5$ & $3 \cdot 59$ & 50 & 36 \\
\hline Phenyl-Sepharose & $20 \cdot 0$ & 68 & $4 \cdot 8$ & $14 \cdot 2$ & 48 & 142 \\
\hline Blue A/DEAE-Sephacel & $4 \cdot 7$ & 28 & 0.47 & $59 \cdot 6$ & 20 & 596 \\
\hline Dialysis & $6 \cdot 0$ & 24 & $0 \cdot 42$ & $57 \cdot 1$ & 17 & 571 \\
\hline \multicolumn{7}{|c|}{ (b) From Sacch. cerevisiae D273-10B } \\
\hline Dialysed extract & 124 & $50 \cdot 6$ & 6200 & $0 \cdot 008$ & 70 & $0 \cdot 7$ \\
\hline DEAE-Sephacel & 76 & $49 \cdot 9$ & 449 & $0 \cdot 111$ & 68 & $9 \cdot 0$ \\
\hline$\left(\mathrm{NH}_{4}\right)_{2} \mathrm{SO}_{4}$ precipitation & $11 \cdot 5$ & $38 \cdot 5$ & 381 & $0 \cdot 101$ & 53 & $8 \cdot 4$ \\
\hline Sephacryl S300HR & 46 & $31 \cdot 8$ & $59 \cdot 8$ & 0.532 & 44 & 44 \\
\hline Phenyl-Sepharose & 39 & $16 \cdot 6$ & 6.63 & $2 \cdot 50$ & 23 & 208 \\
\hline Red A & 34 & $18 \cdot 9$ & $0 \cdot 44$ & $43 \cdot 0$ & 26 & 3763 \\
\hline Dialysis & 40 & $13 \cdot 1$ & $0 \cdot 34$ & $38 \cdot 5$ & 15 & 3369 \\
\hline
\end{tabular}

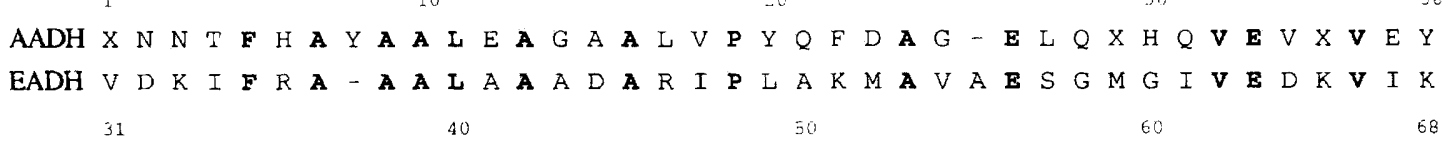

Fig. 1. N-terminal amino acid sequence of the NADP-dependent alcohol dehydrogenase from $A$. calcoaceticus NCIB 8250 . The $\mathrm{N}$-terminal amino acid sequence (AADH) was determined for two separate samples of enzyme containing approx. $12 \mathrm{pmol}$ and $35 \mathrm{pmol}$ of protein (see Methods). The N-terminal amino acid sequence of NADP-dependent alcohol dehydrogenase of $A$. calcoaceticus NCIB 8250 is compared with that of the fermentative alcohol dehydrogenase of $E$. coli (EADH; Goodlove et al., 1989). Identical residues are shown in bold type. The residue number (with reference to the $\mathrm{N}$ terminus) is shown above (for $A A D H$ ) or below (for EADH); $X$, unknown residue; -, gap inserted.

whereas that of the eukaryotic enzyme was $46200(47800$, $45700)$. The subunit $M_{\mathrm{r}}$ of the prokaryotic enzyme, estimated using calibrated SDS-PAGE gels, was $40300 \pm 2000(n=10$ samples of enzyme) whereas that of the eukaryotic enzyme was $43500 \pm 700(n=5$ samples of enzyme). From a comparison of the subunit and native $M_{\mathrm{r}}$ values, the prokaryotic enzyme appears to be a tetramer and the eukaryotic enzyme a monomer.

\section{Absorption spectrum of the prokaryotic enzyme}

The absorption spectrum of NADP-dependent alcohol dehydrogenase $\left(60 \mu \mathrm{g} \mathrm{m}^{-1}\right)$ from $A$. calcoaceticus had a maximum at $280 \mathrm{~nm}$; there was very little absorbance between 300 and $340 \mathrm{~nm}$ and none above $340 \mathrm{~nm}$, indicating that, unlike some alcohol dehydrogenases, the enzyme is not associated with bound cytochrome, haem, PQQ or flavin as prosthetic group.

\section{$\mathrm{N}$-terminal amino acid sequence of the prokaryotic enzyme}

The sequence of the first 38 amino acids of NADPdependent alcohol dehydrogenase from $A$. calcoaceticus was determined (PIR accession number E37334) and then compared with other protein sequences. The only other alcohol dehydrogenase, or related enzyme, to which any significant homology was observed was a fermentative alcohol dehydrogenase from E. coli (see Fig. 1 and Discussion).

Attempts at determining the $\mathrm{N}$-terminal amino acid 
sequence of the eukaryotic enzyme were unsuccessful, perhaps because it is blocked.

\section{Effects of $\mathrm{pH}$ on enzyme activities}

The optimal $\mathrm{pH}$ for alcohol oxidation by the prokaryotic enzyme was $\mathrm{pH} 10 \cdot 2$ and that for the eukaryotic enzyme was $\mathrm{pH} 10 \cdot 7$. The $\mathrm{pH}$ optimum of aldehyde reduction by both enzymes lies at around $\mathrm{pH} 6.8$, although the reaction rate was high ( $>95 \%$ of maximal rate) over a broad range of $\mathrm{pH}(\mathrm{pH} 6 \cdot 4-7 \cdot 15)$.

The isoelectric point of the enzyme from $A$. calcoaceticus was at $\mathrm{pH} 5.7$ as judged by chromatofocussing on an FPLC Mono P column.

\section{Cofactor specificity and stereospecificity of hydride transfer}

Neither enzyme detectably $(<1 \%)$ reduced $\mathrm{NAD}^{+}$when assayed with $1 \mathrm{mM} \mathrm{NAD}^{+}$instead of $1 \mathrm{mM} \mathrm{NADP}^{+}$in the reaction mixture.

The stereospecificity of hydride transfer was determined by incubating the enzymes in the presence of $(4 S)$ - [4$\left.{ }^{3} \mathrm{H}\right] \mathrm{NADPH}$ or $(4-\mathrm{R})-\left[4{ }^{3} \mathrm{H}\right] \mathrm{NADPH}$ and butanal. The criteria used to determine the stereospecificity were as follows. If incubating the enzyme with (4S)-[4$\left.{ }^{3} \mathrm{H}\right] \mathrm{NADPH}$ and butanal resulted in most of the radioactivity being identified in butan-1-ol the enzyme would have transferred the ${ }^{3} \mathrm{H}$-labelled pro- $S$ hydride. However, if the radioactivity was found in $\mathrm{NADP}^{+}$the enzyme would have transferred the unlabelled pro- $R$ hydride.

Similarly, if incubating the enzyme with (4-R)-[4$\left.{ }^{3} \mathrm{H}\right] \mathrm{NADPH}$ and butanal resulted in most of the radioactivity being identified in butan-1-ol, the enzyme would have transferred the ${ }^{3} \mathrm{H}$-labelled pro- $\mathrm{R}$ hydride. However, if the radioactivity was identified in $\mathrm{NADP}^{+}$then the enzyme would have transferred the unlabelled pro- $S$ hydride.

When the prokaryotic enzyme was incubated with butanal and $(4 S)-\left[4-{ }^{3} \mathrm{H}\right] \mathrm{NADPH}$ the ratio of counts incorporated into the resulting NADP $^{+}$and butan-1-ol was $92.5 \%: 7 \cdot 5 \%$, respectively, i.e. the prokaryotic enzyme was stereospecific for the pro-R hydride of NADPH. This was confirmed by incubation of the enzyme with butanal and $(4-\mathrm{R})-\left[4{ }^{3} \mathrm{H}\right] \mathrm{NADPH}$, the ratio of counts incorporated into the resulting $\mathrm{NADP}^{+}$and butan-1-ol being $22 \cdot 7 \%: 77 \cdot 3 \%$, respectively.

Similarly, when the eukaryotic enzyme was incubated with butanal and $(4 S)-\left[4{ }^{3} \mathrm{H}\right] \mathrm{NADPH}$ the ratio of counts incorporated into the resulting $\mathrm{NADP}^{+}$and butanal was $92.5 \%: 7 \cdot 5 \%$, respectively, i.e. this enzyme also was stereospecific for the pro-R hydride of NADPH. This was confirmed by incubation of the enzyme with butanal and (4-R)- $\left[4{ }^{3} \mathrm{H}\right] \mathrm{NADPH}$, the ratio of counts incorporated into the resulting $\mathrm{NADP}^{+}$and butan-1-ol being $30 \cdot 0 \%: 70 \cdot 0 \%$, respectively.
Effects of metal-binding agents, salts, metal ions and common metabolites on the activities of the enzymes

Pre-incubation of the prokaryotic enzyme $\left(5 \mu \mathrm{g} \mathrm{ml}^{-1}\right)$ with EDTA $(100 \mathrm{mM})$, sodium azide $(100 \mathrm{mM})$, pyrazole $(50 \mathrm{mM}), 2,2^{\prime}$-bipyridyl $(20 \mathrm{mM})$ or 8 -hydroxyquinoline $\left[10 \mathrm{mM}\right.$, in $10 \%(\mathrm{v} / \mathrm{v})$ acetone] at $27^{\circ} \mathrm{C}$ for $20 \mathrm{~min}$ had no significant effect on the activity when the enzyme was subsequently assayed in the presence of the potential inhibitor at the same concentration as that used in the preincubation. Incubation of the eukaryotic enzyme $\left(5 \mu \mathrm{g} \mathrm{ml}^{-1}\right)$ at $27^{\circ} \mathrm{C}$ for $20 \mathrm{~min}$ with pyrazole $(50 \mathrm{mM})$ or $2,2^{\prime}$-bipyridyl $(20 \mathrm{mM})$ had no significant effect on enzyme activity. However, incubation of this enzyme with $10 \mathrm{mM}$ EDTA or $10 \mathrm{mM}$ sodium azide did result in 20 and $40 \%$ inhibition, respectively.

No significant effect (i.e. less than $10 \%$ variation in enzyme activity) was observed when the prokaryotic enzyme $\left.(5 \mu \mathrm{g} \mathrm{ml})^{-1}\right)$ was pre-incubated at $27^{\circ} \mathrm{C}$ for $5 \mathrm{~min}$ with $1 \mathrm{mM}$ concentrations of each of the following salts and common metabolites and then assayed for activity in the presence of the salt or metabolite at the same concentration as that used in the pre-incubation: $\mathrm{NaCl}$; $\mathrm{KCl} ;\left(\mathrm{NH}_{4}\right)_{2} \mathrm{SO}_{4} ; \mathrm{ZnCl}_{2} ; \mathrm{CuCl}_{2} ; \mathrm{MgSO}_{4} ; \mathrm{MgCl}_{2} ; \mathrm{MnCl}_{2}$; $\mathrm{FeSO}_{4} ; \mathrm{FeCl}_{3} ; \mathrm{ATP}_{-\mathrm{Mg}^{2+}}$; $\mathrm{ADP}-\mathrm{Mg}^{2+}$; acetyl-CoA; succinate.

\section{Effects of thiol-blocking agents}

Pre-incubation of the prokaryotic enzyme $\left(5 \mu \mathrm{g} \mathrm{ml}^{-1}\right)$ at $27^{\circ} \mathrm{C}$ for $20 \mathrm{~min}$ with the thiol-blocking agents iodoacetate $(10 \mathrm{mM})$, iodoacetamide $(10 \mathrm{mM})$ or $N$-ethylmaleimide $(10 \mathrm{mM})$ had no effect on activity when the enzyme was subsequently assayed in the presence of the potential inhibitor at the same concentration as that used in the pre-incubation. However, incubation of the enzyme with $10 \mu \mathrm{M}$ 4-chloromercuribenzoate completely inhibited the enzyme, but no protection from this inhibition was observed in the presence of hexan-1-ol (5 mM) and/or $\operatorname{NADP}^{+}(1 \mathrm{mM})$.

Incubation of the eukaryotic enzyme $\left(5 \mu \mathrm{g} \mathrm{ml} \mathrm{m}^{-1}\right)$ at $27^{\circ} \mathrm{C}$ with iodoacetate $(10 \mathrm{mM})$ had no effect on enzyme activity. However, incubation of the enzyme with iodoacetamide $(1 \mathrm{mM}), \quad N$-ethylmaleimide $(1 \mathrm{mM})$ or 4 chloromercuribenzoate $(10 \mu \mathrm{M})$ completely inhibited the enzyme. No protection of the inhibition resulting from incubation with $10 \mathrm{mM}$ iodoacetamide or $10 \mathrm{mM} \mathrm{N}$ ethylmaleimide was observed in the presence of hexan-1ol $(10 \mathrm{mM})$ or $\mathrm{NADP}^{+}(1 \mathrm{mM})$. However, some protection of the partial inhibition resulting from $1 \mu \mathrm{M} 4$ chloromercuribenzoate occurred in the presence of $1 \mathrm{mM} \mathrm{NADP}{ }^{+}$, and almost complete protection occurred in the presence of $10 \mathrm{mM}$ hexan-1-ol.

\section{Substrate specificity and kinetic coefficients}

The prokaryotic enzyme. The NADP-dependent al cohol dehydrogenase of $A$. calcoaceticus NCIB 8250 is specific for primary aliphatic alcohols (Table 3). There 
Table 3. Relative activities of NADP-dependent alcohol dehydrogenase of $A$. calcoaceticus NCIB 8250 with various alcohols as substrates

The enzyme was assayed as described in Methods except that the substrates listed below were used in place of hexan-1-ol; all substrates were at $50 \mathrm{mM}$ except for $c i$ s-hex-3-en-1-ol, which was at $10 \mathrm{mM}$. The relative activity of the enzyme towards each substrate is given with respect to the activity with hexan-1-ol, which was 57.3 units (mg protein $)^{-1}$.

\begin{tabular}{|lc|}
\hline Substrate & $\begin{array}{c}\text { Activity as \% } \\
\text { of activity with } \\
\text { hexan-1-ol }\end{array}$ \\
\hline Ethanol & $8 \cdot 5$ \\
Ethanediol & $8 \cdot 5$ \\
Propan-1-ol & $28 \cdot 0$ \\
Allyl alcohol & $28 \cdot 0$ \\
Butan-1-ol & $36 \cdot 3$ \\
Butan-1,4-diol & $29 \cdot 0$ \\
Pentan-1-ol & 133 \\
Ribitol & $4 \cdot 0$ \\
Hexan-1-ol & 100 \\
Mannitol & $6 \cdot 5$ \\
cis-Hex-3-en-1-ol & $18 \cdot 7$ \\
\hline
\end{tabular}

was no activity with: the aliphatic alcohols methanol, propan-2-ol, butan-2,3-diol, pentan-2-ol, hex-5-en-1-ol or octan-2-ol; the cyclic alcohols hexahydrobenzyl alcohol, phenyl ethanol or cyclohexanol; the amino acid alcohols serine, threonine or histidinol; or the sugars glyceraldehyde, erythritol, glucose, fructose or galactose. Primary aliphatic alcohols with more than about ten carbons are practically insoluble in water (Hodgman et al., 1959) and were made accessible as substrates to the enzyme by pre-sonication of alcohol in the presence of BSA. When hexan-1-ol was treated by this method the activity measured was only a third to a quarter of that measured when the enzyme was assayed normally (Table 4). A decrease in activity was observed with increasing chainlength of the primary alcohol substrate at the concentrations assayed. The activity of the enzyme with tetradecan-1-ol as substrate was very low, and no activity was observed with hexadecan-1-ol (Table 4).

Unlike some other alcohol dehydrogenases (Koivusalo \& Uotila, 1991; Pocker \& Li, 1991), the enzyme did not oxidize formaldehyde $(50 \mathrm{mM})$ and acetaldehyde $(50 \mathrm{mM})$ in the presence or absence of coenzyme A or glutathione at $\mathrm{pH} 10 \cdot 2$ (in $80 \mathrm{mM}$ glycine/ $\mathrm{NaOH}$ buffer) or at $\mathrm{pH} 7 \cdot 2$ (in $50 \mathrm{mM}$ Tris/ $\mathrm{HCl}$ buffer).

The $K_{\mathrm{m} \text { (app) }}$ values for primary alcohols decreased as the chain-length of the primary alcohol increased from ethanol to hexan-1-ol/octan-1-ol (Table 5a). The $V_{\max (a p p)}$ values increased as chain-length increased from ethanol to pentan-1-ol, then decreased with increasing chain-length to octan-1-ol. The NADP-dependent alcohol dehydrogenase partially purified from strain $\mathrm{HO} 1-\mathrm{N}$ of A. calcoaceticus by Fox et al. (1992) also had very little
Table 4. Ability of NADP-dependent alcohol dehydrogenase of A. calcoaceticus NCIB 8250 to oxidize alcohols with long chain-lengths

All of the alcohols used were pre-sonicated in BSA $\left(0.7 \mathrm{mg} \mathrm{m}^{-1}\right)$ and assayed as described in Methods. The apparent concentration is based on the concentration of the alcohol that was sonicated. Values in parentheses refer to activities with no sonication with BSA at these alcohol concentrations. ND, Not determined.

\begin{tabular}{|c|c|c|}
\hline Alcohol & $\begin{array}{l}\text { Apparent } \\
\text { concn } \\
(\mathrm{mM})\end{array}$ & $\begin{array}{c}\text { Activity } \\
{\left[\text { nmol min } \text { min }^{-1}\right.} \\
\left.(\text { mg protein })^{-1}\right]\end{array}$ \\
\hline Hexan-1-ol & $\begin{array}{l}500 \\
250 \\
100\end{array}$ & $\begin{array}{l}8.80(31 \cdot 0) \\
6.60(21 \cdot 4) \\
3.00(10 \cdot 1)\end{array}$ \\
\hline Octan-1-ol & $\begin{array}{l}500 \\
250 \\
100\end{array}$ & $\begin{array}{l}7 \cdot 45 \\
5 \cdot 05 \\
2 \cdot 50\end{array}$ \\
\hline Decan-1-ol & $\begin{array}{l}500 \\
250 \\
100\end{array}$ & $\begin{array}{l}6 \cdot 50 \\
3 \cdot 05 \\
1 \cdot 20\end{array}$ \\
\hline Dodecan-1-ol & $\begin{array}{l}500 \\
250 \\
100\end{array}$ & $\begin{array}{l}3 \cdot 40 \\
3 \cdot 65 \\
2 \cdot 65\end{array}$ \\
\hline Tetradecan-1-ol & $\begin{array}{l}500 \\
250 \\
100\end{array}$ & $\begin{array}{l}0 \cdot 35 \\
0 \cdot 25 \\
0 \cdot 10\end{array}$ \\
\hline Hexadecan-1-ol & $\begin{array}{l}500 \\
250 \\
100\end{array}$ & $\begin{array}{l}\text { ND } \\
0 \cdot 00 \\
0 \cdot 00\end{array}$ \\
\hline
\end{tabular}

activity with substrates containing more than $12 \mathrm{C}$-atoms, but the $K_{\mathrm{m} \text { (app) }}$ value seemed to decrease as the chainlength increased.

Butanal was used as a typical aldehyde rather than hexanal or a higher-chain aldehyde because of the very low solubilities of the latter (Hodgman et al., 1959). The $K_{\mathrm{m} \text { (app) }}$ value for butanal was much lower than that for butan-1-ol (3.97 $\mathrm{mM}$ and $52.7 \mathrm{mM}$, respectively). In addition, the $K_{\mathrm{m}(\mathrm{app})}$ value for NADPH was lower than that for $\operatorname{NADP}^{+}(4.3 \mu \mathrm{M}$ and $38 \mu \mathrm{M}$, respectively) although the $K_{\mathrm{m} \text { (app) }}$ of both cofactors was very much lower than that of either alcohol or aldehyde. The $V_{\max (a p p)}$ was slightly lower for butanal than for butan1-ol [39.2 units (mg protein) ${ }^{-1}$ and $57 \cdot 1$ units (mg protein) $)^{-1}$, respectively] (Table 5a).

$K_{\mathrm{m}(\mathrm{app})}$ and $V_{\max (\mathrm{app})}$ values of the enzyme for hexan-1ol were also determined at $\mathrm{pH} 7.2$ in $80 \mathrm{mM}$ Tris buffer (otherwise the enzyme was assayed as before). This $\mathrm{pH}$ value was chosen because it was as close to the $\mathrm{pH}$ optimum of aldehyde reduction ( $\mathrm{pH}$ 6.8) as the alcohol oxidation reaction could be reasonably assayed at. The $K_{\text {m(app) }}$ and $V_{\max (a p p)}$ values were $12.1 \mathrm{mM}(68 \%$ confidence limits, 11.4-17.2) and $41 \cdot 0$ units $(\mathrm{mg} \text { protein })^{-1}(68 \%$ confidence limits, 38.1-56.4), re- 
Table 5. Kinetic constants of selected substrates of NADP-dependent alcohol dehydrogenases

The $K_{\text {m(app) }}$ and $I_{\max (a p p)}$ values for the substrates were determined by measuring the initial reaction rates at various nonsaturating concentrations of that substrate in the presence of a fixed, high concentration of the other substrate $\left(1 \mathrm{mM} \mathrm{NADP}{ }^{+}\right.$, $20 \mu \mathrm{M}$ NADPH, $20 \mathrm{mM}$ hexan-1-ol or $20 \mathrm{mM}$ butanal as appropriate) at $\mathrm{pH} 10 \cdot 2$ (for the prokaryotic enzyme) or $\mathrm{pH} 10 \cdot 7$ (for the eukaryotic enzyme). The standard assay mixtures were used except that the concentration of one of the substrates was varied. Aldehyde reduction was assayed fluorimetrically at $\mathrm{pH}$ 6.8. The second substrates used in determination of kinetic constants for the cofactors are given in parentheses. The kinetic constants were calculated by the Direct Linear method. Where only one value was determined the $68 \%$ confidence limits are given in parentheses. Where two values were determined for a kinetic constant the average is given with the actual values in parentheses. Where more than two values were determined the mean is given with the standard deviation and the sample size in parentheses. ND, Not determined.

\begin{tabular}{|c|c|c|}
\hline Substrate & $\begin{array}{l}K_{\mathrm{m}(\mathrm{app})} \\
(\mathrm{mM})\end{array}$ & $\begin{array}{c}V_{\max (\text { app) }} \\
{[\text { units }} \\
\left.(\mathrm{mg} \text { protein })^{-1}\right]\end{array}$ \\
\hline \multicolumn{3}{|c|}{$\begin{array}{l}\text { (a) Alcohol dehydrogenase from A. calcoaceticus } \\
\text { NCIB } 8250\end{array}$} \\
\hline Ethanol & $727(750,703)$ & $20 \cdot 8(21 \cdot 7,19 \cdot 9)$ \\
\hline Butan-1-ol & $52 \cdot 7(51 \cdot 6,53 \cdot 7)$ & $57 \cdot 1(58 \cdot 2,57 \cdot 6)$ \\
\hline Pentan-1-ol & $5 \cdot 80(5 \cdot 82,5 \cdot 78)$ & $66 \cdot 7(65 \cdot 9,67 \cdot 4)$ \\
\hline Hexan-1-ol & $1 \cdot 22(0 \cdot 20, n=4)$ & $58 \cdot 8(2 \cdot 44, n=4)$ \\
\hline Heptan-1-ol & $1.09(0.94-1.30)$ & $58 \cdot 0(53 \cdot 7-65 \cdot 4)$ \\
\hline Octan-1-ol & $1 \cdot 10(1 \cdot 01,1 \cdot 21)$ & $37 \cdot 9(38 \cdot 8,37 \cdot 1)$ \\
\hline Benzyl alcohol & $15 \cdot 0(8 \cdot 3-18 \cdot 3)$ & $57 \cdot 5(55 \cdot 0-65 \cdot 8)$ \\
\hline Butanal & $3.97(3.22,4.71)$ & $39 \cdot 2(39 \cdot 3,39 \cdot 0)$ \\
\hline $\begin{array}{l}\text { NADP } \\
\text { (hexan-1-ol) }\end{array}$ & $\begin{array}{l}38 \cdot 0 \times 10^{-3} \\
\left(39 \cdot 7 \times 10^{-3}, 36 \cdot 2 \times 10^{-3}\right)\end{array}$ & ND \\
\hline $\begin{array}{l}\text { NADPH } \\
\text { (butan-1-ol) }\end{array}$ & $\begin{array}{c}4.33 \times 10^{-3} \\
\left(3.77 \times 10^{-3}, 4.88 \times 10^{-3}\right)\end{array}$ & ND \\
\hline \multicolumn{3}{|c|}{$\begin{array}{l}\text { (b) Alcohol dehydrogenase of Sacch. cerevisiae } \\
\text { D273-10B }\end{array}$} \\
\hline Ethanol & $4790(3440-9900)$ & $48 \cdot 4(38 \cdot 4-68 \cdot 2)$ \\
\hline Butan-1-ol & $78 \cdot 6(77 \cdot 1,80 \cdot 0)$ & $69 \cdot 8(76 \cdot 9,62 \cdot 7)$ \\
\hline Pentan-1-ol & $14 \cdot 1(12 \cdot 7,15 \cdot 4)$ & $86 \cdot 7(93 \cdot 8,79 \cdot 7)$ \\
\hline Hexan-1-ol & $6.8(5.9,7.6)$ & $55 \cdot 6(66 \cdot 1,45 \cdot 1)$ \\
\hline Octan-1-ol & $6 \cdot 2(5 \cdot 4,7 \cdot 0)$ & $54 \cdot 9(68 \cdot 2,41 \cdot 6)$ \\
\hline Butanal & $0.75(0.71,0.79)$ & $27 \cdot 1(24 \cdot 7,29 \cdot 4)$ \\
\hline $\begin{array}{l}\text { NADP } \\
\text { (hexan-1-ol) }\end{array}$ & $\begin{array}{l}20 \cdot 2 \times 10^{-3} \\
\left(15 \cdot 8 \times 10^{-3}, 24.6 \times 10^{-3}\right)\end{array}$ & ND \\
\hline $\begin{array}{l}\text { NADPH } \\
\text { (butanal) }\end{array}$ & $\begin{array}{l}7 \cdot 9 \times 10^{-4} \\
\left(6 \cdot 7 \times 10^{-4}, 9 \cdot 0 \times 10^{-4}\right)\end{array}$ & ND \\
\hline
\end{tabular}

spectively. This $K_{\mathrm{m}(\mathrm{app})}$ value is tenfold higher than, and the $V_{\max (a p p)}$ value $70 \%$ of, that obtained at $\mathrm{pH} 10 \cdot 2$, which suggests that these variations are because of ionizations in the free enzyme as opposed to the enzyme substrate complex (Fersht, 1985).
Table 6. Apparent turnover numbers and specificity constants for selected substrates of NADP-dependent alcohol dehydrogenases

Apparent turnover numbers $\left(k_{\text {cat(app) }}\right)$ and specificity constants $\left(k_{\text {cat(app) }} / K_{\mathrm{m} \text { (app) }}\right)$ were determined using the mean values for kinetic coefficients given in Table 5 assuming that there was one active site per enzyme subunit, that the subunit $M_{\mathrm{r}}$ values of the prokaryotic and eukaryotic enzymes were 40300 and 43500 , respectively, and that $V_{\max (a p p)}=k_{\text {cat(app) }} \times\left[\mathrm{E}_{\mathrm{t}}\right]$, where $\left[\mathrm{E}_{\mathrm{t}}\right]$ is the concentration of active sites.

\begin{tabular}{|c|c|c|}
\hline Substrate & $k_{\mathrm{cat}(\mathrm{app})}\left(\mathrm{s}^{-1}\right)$ & $\begin{array}{l}k_{\mathrm{cat}(\mathrm{app})} / K_{\mathrm{m}(\mathrm{app})} \\
\left(\mathrm{s}^{-1} \mathbf{M}^{-1}\right)\end{array}$ \\
\hline \multicolumn{3}{|c|}{$\begin{array}{l}\text { (a) Alcohol dehydrogenase from A. calcoaceticus } \\
\text { NCIB } 8250\end{array}$} \\
\hline Ethanol & $13 \cdot 9$ & $1.90 \times 10^{1}$ \\
\hline Butan-1-ol & $38 \cdot 3$ & $7 \cdot 26 \times 10^{2}$ \\
\hline Pentan-1-ol & $44 \cdot 7$ & $7 \cdot 71 \times 10^{3}$ \\
\hline Hexan-1-ol & $39 \cdot 4$ & $3 \cdot 23 \times 10^{4}$ \\
\hline Heptan-1-ol & $38 \cdot 9$ & $3.57 \times 10^{4}$ \\
\hline Octan-1-ol & $25 \cdot 4$ & $2 \cdot 31 \times 10^{4}$ \\
\hline Butanal & $26 \cdot 3$ & $6.62 \times 10^{3}$ \\
\hline \multicolumn{3}{|c|}{$\begin{array}{l}\text { (b) Alcohol dehydrogenase from Sacch. cerevisiae } \\
\text { D273-10B }\end{array}$} \\
\hline Ethanol & $35 \cdot 1$ & $7 \cdot 3$ \\
\hline Butan-1-ol & $50 \cdot 6$ & $6.4 \times 10^{2}$ \\
\hline Pentan-1-ol & $62 \cdot 9$ & $4.5 \times 10^{3}$ \\
\hline Hexan-1-ol & $40 \cdot 3$ & $5 \cdot 8 \times 10^{3}$ \\
\hline Octan-1-ol & $39 \cdot 8$ & $6.4 \times 10^{3}$ \\
\hline Butanal & $19 \cdot 6$ & $2.6 \times 10^{4}$ \\
\hline
\end{tabular}

The highest turnover number of the enzyme was for pentan-1-ol as substrate. The highest specificity constants of the enzyme were for hexan-1-ol and heptan-1-ol as substrates (Table 6a).

The eukaryotic enzyme. This enzyme utilized primary alcohols with from two to at least eight carbons (Table $5 b)$. No activity was observed with the secondary alcohol pentan-2-ol. The $K_{\mathrm{m} \text { (app) }}$ values for primary alcohols decreased from ethanol to hexan-1-ol and octan-1-ol. The $V_{\max (a p p)}$ values increased as chain-length increased from ethanol to pentan-1-ol, then decreased slightly (Table 5b). The $V_{\max \text { app }}$ value determined for the aldehyde butanal was only half that of its equivalent alcohol butan-1-ol. However, the $K_{\mathrm{m}(\mathrm{app})}$ value for butanal was much lower than that of butan-1-ol. Similarly, the $K_{\mathrm{m}(\mathrm{app})}$ for NADPH was much lower than for $\mathrm{NADP}^{+}$, although the $K_{\mathrm{m}(\mathrm{app})}$ of both cofactors was much lower than that of the alcohol or the aldehyde.

The highest turnover number of the enzyme was for pentan-1-ol as substrate (Table 6b). The highest specificity constants for primary alcohols were for hexan-1-ol and octan-1-ol as substrates, but butanal had a 100-fold higher specificity constant than the primary alcohols. 


\section{DISCUSSION}

This work was originally aimed at characterizing the NADP-dependent alcohol dehydrogenase of $A$. calcoaceticus but we found that not only was an apparently similar enzyme present in all the eubacteria that we examined, but it was also present in the two yeasts, Rbodotorula graminis and Sacch. cerevisiae (Table 1). Although four different alcohol dehydrogenases from $S$. cerevisiae have been purified and characterized, and their amino acid sequences deduced from their gene sequences (Brändén et al., 1975; Young \& Pilgrim, 1985; Williamson \& Paquin, 1987), all of these enzymes are inducible, NAD-dependent and optimally use $\mathrm{C}_{2}-\mathrm{C}_{4}$ alcohols as substrates. As such, they seem very different from the constitutive NADP-dependent hexan-1-ol dehydrogenase activity identified in the present work. The identification of such constitutive alcohol dehydrogenase activities in a wide variety of both prokaryotic and eukaryotic organisms may well open the door to a whole new group of these enzymes in terms of their structures and of their physiological role.

Comparison of the $\mathrm{N}$-terminal amino acid sequence obtained for the enzyme from $A$. calcoaceticus with those of the other alcohol dehydrogenases described in the literature reveals no significant sequence identities except for a $34 \%$ identity with residues $31-68$ of a fermentative alcohol dehydrogenase from E. coli (Fig. 1). The E. coli enzyme has been identified as a member of the group 3 alcohol dehydrogenases but it is somewhat unusual in that it is much larger than the other enzymes in this group, being a dimer of subunit $M_{\mathrm{r}}$ value 96000 and shows both ethanol and CoA-linked acetaldehyde dehydrogenase activity (Goodlove et al., 1989). A further complication is that although it is the C-terminal half of the protein that shows homology with group 3 alcohol dehydrogenases, when the C-terminal third of the gene is removed the resulting protein shows only the ethanol dehydrogenase activity (Clark, 1992). These confusing, and apparently contradictory, findings make it difficult to assess the significance of the identity between the Acinetobacter enzyme and the $E$. coli enzyme.

The subunit $M_{\mathrm{r}}$ values of both the Acinetobacter and the Saccharomyces enzymes are consistent with these enzymes belonging to either the group 1 or group 3 alcohol dehydrogenases. However, the apparent monomeric structure of the eukaryotic enzyme is somewhat unusual among alcohol dehydrogenases, most being dimers or tetramers. There is little evidence for the existence of a metal ion in either of these enzymes as judged by their lack of inhibition by metal-binding agents. However, it may be that harsher conditions would be needed to inhibit the enzyme in this kind of experiment, e.g. heating in the presence of chelating agents (DeBruyn et al., 1981). Both enzymes appear to use only $\mathrm{NADP}^{+}$as cofactor and both transfer the pro- $R$ hydrogen to/from NADP $(\mathrm{H})$. The three structural groups of alcohol dehydrogenases show different stereospecificities. The group 2 enzymes transfer the pro- $S$ hydrogen, whereas both groups 1 and 3 transfer the pro- $R$ hydrogen (Glasfeld \& Benner, 1989).
The eukaryotic enzyme shows similar substrate specificities to the prokaryotic enzyme, oxidizing primary alcohols with $\mathrm{NADP}^{+}$, not $\mathrm{NAD}^{+}$, as cofactor. In terms of its kinetic coefficients for alcohol oxidation the yeast enzyme is less efficient than the bacterial enzyme; $K_{\mathrm{m}(\mathrm{app})}$ values are two- to eightfold lower, $V_{\max (a p p)}$ values are slightly higher, and consequently specificity constants are up to fivefold lower. Aldehyde reduction is kinetically favoured over alcohol oxidation in the reaction catalysed by both enzymes, given that their $K_{\mathrm{m} \text { (app) }}$ values for aldehyde are much lower than those for the corresponding alcohol but it is unclear whether this has any physiological significance. There are some differences in the effects of thiol-blocking agents on the enzymes, the yeast enzyme being susceptible to a wider variety of such compounds.

Overall, there are enough structural and kinetic similarities between the eukaryotic and prokaryotic enzymes to suggest that the enzymes may be homologous and that they may have the same physiological role. Furthermore, the existence of NADP-dependent aliphatic alcohol dehydrogenase activities in a variety of different microorganisms grown under conditions unlikely to induce such activities implies that these enzymes may be ubiquitous in the microbial world, carrying out some common function as yet undefined.

\section{ACKNOWLEDGEMENTS}

We are grateful to Dr J. N. Keen, who did the $\mathrm{N}$-terminal sequence analysis, and to Dr D. P. Baker, Dr A. M. Cook and Ms S. Strolmeyer, who participated in the experiments on the stereospecificity of hydride transfer at the ETH, Zürich. M.R.W. acknowledges receipt of a research studentship from the UK Science and Engineering Research Council.

\section{REFERENCES}

Allison, N., O'Donnell, M. J., Hoey, M. E. \& Fewson, C. A. (1985). Membrane-bound lactate dehydrogenases and mandelate dehydrogenases of Acinetobacter calcoaceticus. Purification and properties. Biochem J 231, 407-416.

Arnold, L. J. , Jr, You, K., Allison, W. S. \& Kaplan, N. O. (1976). Determination of the hydride transfer stereospecificity of nicotinamide adenine dinucleotide linked oxidoreduction by proton magnetic resonance. Biochemistry 15, 4844-4849.

Asperger, O. \& Kleber, H.-P. (1991). Metabolism of alkanes by Acinetobacter. In The Biology of Acinetobacter, pp. 323-350. Edited by K. J. Towner, E. Bergogne-Bérézin \& C. A. Fewson. New York and London: Plenum Press.

Baker, M. E. (1990). Sequence similarity between Pseudomonas dihydrodiol dehydrogenase, part of the gene cluster that metabolizes polychlorinated biphenyls, and dehydrogenases involved in the metabolism of ribitol and glucitol and synthesis of antibiotics and $17 \beta$-oestradiol, testosterone and corticosterone. Biocbem J 267, 839-841.

Baker, D. P. \& Fewson, C. A. (1989). Purification and characterization of $\mathrm{D}(-)$-mandelate dehydrogenase from Rbodotorula graminis. J Gen Microbiol 135, 2035-2044.

Baker, D. P., Kleanthous, C., Keen, J. N. \& Fewson, C. A. (1992). Mechanistic and active site studies on $\mathrm{D}(-)$-mandelate dehydrogenase from Rhodotorula graminis. Biocbem J 281, 211-218. 
Blakely, R. L., Ramasastri, B. V. \& McDougall, B. M. (1963). The biosynthesis of thymidylic acid. V. Hydrogen isotope studies with dihydrofolate reductase and thymidylate synthetase. $J$ Biol Chem 238, 3075-3079.

Brändén, C.-I., Jörnvall, H., Eklund, H. \& Furugren, B. (1975). Alcohol dehydrogenases. In The Enzymes, 3rd edn, vol. XI, pp. 103-190. Edited by P. D. Boyer. London: Academic Press.

Clark, D. P. (1992). Evolution of bacterial alcohol metabolism. In The Evolution of Metabolic Function, pp. 105-114. Edited by R. P. Mortlock. Boca Raton, Ann Arbor, London: CRC Press.

DeBruyn, J., Johannes, A., Weckx, M. \& Beumer-Johannes, M.-P. (1981). Partial purification and characterization of a NADPdependent broad specificity alcohol dehydrogenase from $M y c o-$ bacterium tuberculosis var bovis. J Gen Microbiol 124, 359-363.

Eisenthal, R. \& Cornish-Bowden, A. (1974). The direct linear plot. Biocbem J 139, 715-720.

Fersht, A. (1985). Enzyme Structure and Mechanism, pp. 392-397. New York: W. H. Freeman.

Findlay, J. B. C., Pappin, D. J. C. \& Keen, J. N. (1989). Automated solid-phase microsequencing. In Protein Sequencing. A Practical Approach, pp. 69-84. Edited by J. B. C. Findlay \& M. Geisgow. Oxford: IRL Press.

Fixter, L. M. \& Nagi, M. N. (1984). The presence of an NADPdependent alcohol dehydrogenase activity in Acinetobacter calcoaceticus. FEMS Microbiol Lett 22, 297-299.

Fox, M. G. A., Dickinson, F. M. \& Ratledge, C. (1992). Long-chain alcohol and aldehyde dehydrogenases in Acinetobacter calcoaceticus strain HO1-N. J Gen Microbiol 138, 1963-1972.

Glasfeld, A. \& Benner, S. A. (1989). The stereospecificity of the ferrous-ion-dependent alcohol dehydrogenase from Zymomonas mobilis. Eur J Biochem 180, 373-375.

Goodlove, P. E., Cunningham, P. R., Parker, J. \& Clark, D. P. (1989). Cloning and sequence analysis of the fermentative alcoholdehydrogenase-encoding gene of Escbericbia coli. Gene 85, 209-214.

Hobbs, G., Frazer, C. M., Gardner, D. C. J., Cullum, J. A. \& Oliver, S. G. (1989). Dispersed growth of Streptomyces in liquid culture. Appl Microbiol Biotechnol 31, 272-277.

Hodgman, C. D., Weast, R. C. \& Selby, S. M. (editors) (1959). Handbook of Chemistry \& Pbysics. Cleveland: Chemical Rubber Publishing.

Holms, W. H. \& Bennett, P. M. (1971). Regulation of isocitrate dehydrogenase activity in Escherichia coli on adaptation to acetate. $J$ Gen Micrabiol 65, 57-68.

Hopwood, D. A., Bibb, M. J., Chater, K. F., Kieser, K., Bruton, C. J., Kieser, H. M., Lydiate, D. J., Smith, C. P., Ward, J. M. \& Schrempf, H. (1985). Genetic Manipulation of Streptomyces: a Laboratory Manual, p. 239. Norwich: John Innes Foundation.

Jörnvall, H., Persson, M. \& Jeffery, J. (1981). Alcohol and polyol dehydrogenases are both divided into two protein types, and structural properties cross-relate the different enzyme activities within each type. Proc Natl Acad Sci US A 78, 4226-4230.

Jörnvall, H., Persson, B. \& Jeffery, J. (1987). Characterization of alcohol/polyol dehydrogenases (zinc-containing long-chain alcohol dehydrogenases). Biochem J 167, 195-201.
Koivusalo, M. \& Uotila, L. (1991). Glutathione-dependent formaldehyde dehydrogenase: evidence for the identity with class III alcohol dehydrogenase. In Envymology and Molecular Biology of Carbonyl Metabolism, vol. 3, pp. 337-345. Edited by H. Weiner, B. Wermuth \& D.W. Crabb. New York \& London: Plenum Press.

Laemmli, U. K. (1970). Cleavage of structural proteins during the assembly of the head of bacteriophage T4. Nature 227, 680-685.

MacKintosh, R. W. \& Fewson, C. A. (1987). Microbial aromatic alcohol and aldehyde dehydrogenases. In Envymology and Molecular Biology of Carbonyl Metabolism, pp. 259-273. Edited by H. Weiner \& T. G. Flynn. New York: Alan R. Liss.

MacKintosh, R. W. \& Fewson, C. A. (1988). Benzyl alcohol dehydrogenase and benzaldehyde dehydrogenase from Acinetobacter calcoaceticus. Purification and properties. Biochem J 250, 743-751.

Murray, K., Dugglesby, C. J., Sala-Trepat, J. M. \& Williams, P. A. (1972). The metabolism of benzoate and methylbenzoates via the meta cleavage pathway. Eur J Biochem 29, 301-310.

Pocker, Y. \& Li, H. (1991). Kinetics and mechanism of methanol and formaldehyde interconversion and formaldehyde oxidation catalysed by liver alcohol dehydrogenase. In Enzymology and Molecular Biology of Carbonyl Metabolism, vol. 3, pp. 337-345. Edited by H. Weiner, B. Wermuth \& D. W. Crabb. New York \& London: Plenum Press.

Reid, G. A. \& Schatz, G. (1982). Import of proteins into mitochondria. J Biol Chem 257, 13056-13061.

Tassin, J.-P. \& Vandecasteele, J.-P. (1971). Etude d'une alcool deshydrogenase utilisant les alcools à longue chaine. C R Acad Sci Paris Se D 272, 1024-1026.

Tassin, J.-P. \& Vandecasteele, J.-P. (1972). Separation and characterization of long-chain alcohol dehydrogenase isoenzymes from Pseudomonas aeruginosa. Biochim Biophys Acta 276, 31-42.

Tauchert, H., Grunow, M., Harnisch, H. \& Aurich, H. (1976). Purification and some properties of NADP-dependent alcohol dehydrogenase from Acinetobacter calcoaceticus. Acta Biol Med Ger 35, 1267-1273.

Thatcher, D. R. \& Sawyer, L. (1980). Secondary structure prediction from the amino acid sequence of Drosophila melanogaster (fruit fly) alcohol dehydrogenase. Biochem J 187, 875-886.

Wales, M. R. \& Fewson, C. A. (1991). Comparison of the primary structures of bacterial alcohol dehydrogenases. In En₹ymology and Molecular Biology of Carbonyl Metabolism, vol. 3, pp. 337-345. Edited by H. Weiner, B. Wermuth \& D. W. Crabb. New York \& London: Plenum Press.

Williams, P. A. (1985). Enzpack. Cambridge: Elsevier-BIOSOFT. Williamson, V. M. \& Paquin, C. E. (1987). Homology of Saccharomyces cerevisiae ADH4 to an iron-activated alcohol dehydrogenase from Zymomonas mobilis. Mol \& Gen Genet 209, 374-381.

Young, E. T. \& Pilgrim, D. (1985). Isolation and DNA sequence of $\mathrm{ADH} 3$, a nuclear gene encoding the mitochondrial isozyme of alcohol dehydrogenase in Saccharomyces cerevisiae. Mol Cell Biol 5, 3025-3034.

Received 24 May 1993; revised 29 July 1993; accepted 4 August 1993. 